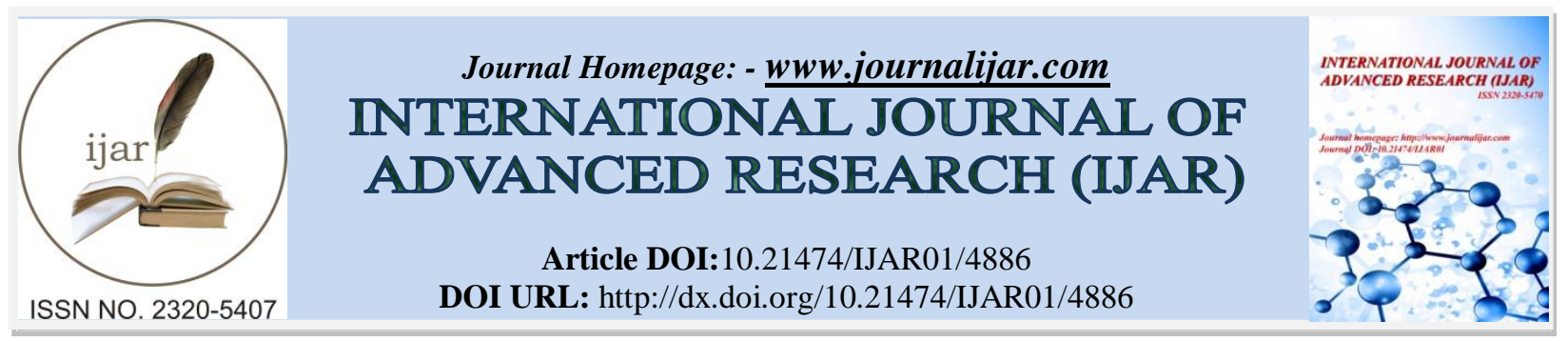

RESEARCH ARTICLE

\title{
FREE FATTY ACID LEVELS IN SOME SURFACE WATERS AND MUNICIPAL WATER SUPPLY OF SOUTH-WESTERN NIGERIA.
}

\author{
${ }^{*}$ Akinnifesi T. A. ${ }^{\mathbf{1}}$, Asubiojo F.O. ${ }^{\mathbf{2}}$, Ogunfowokan A.O. ${ }^{\mathbf{2}}$, Okonkwo O. J. ${ }^{3}$, Ololade I. A ${ }^{\mathbf{1}}$ and Oladoja N. A ${ }^{\mathbf{1}}$. \\ 1. Lecturer, Department of Chemical Sciences, Adekunle Ajasin University. Akungba- Akoko, Nigeria. \\ 2. Professor, Department of Chemistry, Obafemi Awolowo University. Ile-Ife, Nigeria. \\ 3. Professor, Department of Environmental Science, Tshwane University of Technology, Pretoria, South Africa.
}

\section{Manuscript Info}

Manuscript History

Received: 19 May 2017

Final Accepted: 21 June 2017

Published: July 2017

Key words:-

Surface water and sediments, treated water, Free fatty acids, extraction, cleanup.

\section{Abstract}

This study investigates the concentration levels of the free fatty acids (which are also important organic pollutants) in surface waters (rivers, streams and lakes) of South-Western Nigeria that are devoid of adequate information. The standard methods based on lipid extraction and isolation and methylation of the free fatty acids were modified and used for the analysis of the free fatty acids in the water samples. $\mathrm{BF}_{3}$-Methanol was used as the methylation reagent. Gas chromatography based on flame ionization detector was used for quantitative analysis of the complex mixtures of the free fatty acids. The average concentration levels of FFAs observed in all the surface (river) water samples of the dry and wet seasons are $24.14 \pm 31.73 \mu \mathrm{g} / \mathrm{L}$ and $23.68 \pm 25.67 \mu \mathrm{g} / \mathrm{L}$ respectively while those of tap waters samples are $21.42 \pm 5.77 \mu \mathrm{g} / \mathrm{L}$ and $34.30 \pm 4.61 \mu \mathrm{g} / \mathrm{L}$ for dry and wet seasons respectively. These represent the baseline data on which further studies on FFAs in surface waters and tap waters of Nigeria could be based. It is concluded that most of the FFAs in the surface waters circulated into the treated drinking waters and that the water treatment plants in the study area have minimal effect on the removal of FFAs (trace organics) from the raw surface waters of Nigeria.

Copy Right, IJAR, 2017,. All rights reserved.

\section{Introduction:-}

Surface water, in its natural state, contains particulate and dissolved materials as well as micro-organisms (Dart and Stretton, 1977; Morgan, 1977; Fondriest Environmental INC, 2016). Pollutants in air or on land washed or leached out by rain also find their way into surface waters. How much of these pollutants, rivers receive every year is difficult to ascertain (Sawkinset al., 1978; Donald et al., 2013). When organic wastes are dumped into rivers and lakes it causes dissolved oxygen to decrease, which causes plants and animals to die (Neighbourhood Water Quality, 2000). Most communities in South-Western Nigeria use water from surface waters especially rivers, streams and dams for variety of purposes such as drinking, fishing, livestock watering and recreational purposes.

Water from the dams (reservoirs) are treated and supplied to the communities around these water sources. The quality of the drinking water supplied to the public from the waterworks' treatment plants depends largely on the quality of the plant and its efficiency in removing the contaminants or pollutants from the raw water (surface water). In developing countries, and Nigeria in particular, surface waters (rivers \& streams) are still used directly by rural 
dwellers as water supply without treatment. It is obvious that treated waters are rarely supplied to the urban dwellers. The quality of the finished drinking water supply to the public will no doubt depend upon the efficiency of the waterworks plants.

Reports in the literature indicate that arterial plaque, diabetes, breast cancer and other cardiovascular diseases are caused by dietary intake of some fatty acids especially from partially hydrogenated polyunsaturated oils (Mann, 1994; Enig, 1995; Holmes, 1999; Byrnes, 2002; Lobnaet al., 2016). The Lipotoxic effects of free fatty acids on islet beta cells have also been demonstrated in the literature (Ayvazet al., 2002; Lizukaet al., 2002; Boden, 2002; Simona and Minodora, 2013). The introduction of such fatty acids into surface waters (streams and rivers) through agricultural, industrial and domestic waste discharges and aquatic biota is very common. Kelley et al. (1959) reported that some marine micro-organisms (plankton) are composed of fatty acids. The presence of free fatty acids in surface waters in developed countries has been reported (Ishiwatari and Hanya, 1974; Ogura et al., 1975; Sheldon and Hites, 1979; Matsumoto, 1981; Fatoki and Vernon, 1989;). Ishiwatari and Hanya (1974) and Ogura et al., (1975) have studied the composition of fatty acids in Toma River of Tokyo area. They reported that the fatty acids are found with predominance of even carbon numbers that ranged from carbon chain length $\mathrm{C}_{12}$ to $\mathrm{C}_{30}$ including unsaturated and branched acids.

High concentration of fatty acids in the river waters may have lethal effect on the aquatic living organisms. The dead organisms may have their fatty acids released into the water body and this may result into oxygen depletion. In water, nutrients may increase the number of living organisms and consequently increase the level of the free fatty acids content of such water body. The danger in the dietary intake of some fatty acids is generally interpreted in terms of their contribution through food alone. However, the free fatty acid intake through drinking water cannot be ignored in assessing the magnitude of the total intake. Generally, studies on the occurrence and distribution of fatty acids in surface waters and drinking waters have received less attention than studies on other aquatic organic pollutants (Fatoki and Vernon, 1989). There is, therefore, a dearth of information on FFA occurrence and levels in Nigeria surface waters and tap (drinking) water sources. As part of our on-going monitoring of rivers and surface waters in Nigeria, the present study is aimed at free fatty acids and their levels in major rivers in South-Western part of Nigeria

\section{Experimental:-}

South-Western Nigeria, is approximate located on grid co-ordinates between $4^{\circ} 30^{1}$ and $9^{0} \mathrm{~N}$ and $2^{\circ} 40^{1}$ and $6^{\circ} 30^{1} \mathrm{E}$ (Ojo-Atereet al., 1990). The study area covers a part of South-Western States of Nigeria (Ondo, Osun, and Lagos states). The sampling sites are some selected major streams and rivers within the study area (Figure 1). There are two distinct seasons in Nigeria: the wet season runs between March to November while the dry season runs from November and ends in March. The study was conducted during the wet and dry seasons between January and September in 2015.

\section{Standards and Reagents:-}

Fatty acid standards and their corresponding methyl esters and internal standard (n-butyl benzoate) were purchased from Sigma and Alltech (Purity was > 95\%). HPLC grade methanol, pentane and hexane were supplied by Fischer Scientific (Leicesleschire, UK). Milli-Q ultra pure water prepared by Millipore (Boston, WA). All the other reagents used in the study were of analytical grade. Sodium chloride, sodium carbonate and anhydrous sodium sulphate were heated in a muffle furnace at $450{ }^{\circ} \mathrm{C}$ for 4 hours before their utilization.

\section{Sample Collection:-}

All sample bottles and glassware used were thoroughly washed with hot detergent solution, concentrated nitric acid, rinsed with distilled water and pure acetone prior to their usage. Thirty (30) surface water samples were collected during dry and wet seasons respectively from ten randomly selected rivers, (Ala, Oluwa, Ogbese, Ose, Owena, Oni, Opa, Osun, Iju, and Iyaalaro) in Ondo, Osun, Lagos and Oyo States of South-Western Nigeria. Twenty four tap (treated) water samples from selected water work plants situated close to the rivers from which raw water samples are treated were also collected for FFA analysis to monitor the migration of the fatty acids into the treated water. Individual surface water samples were collected in triplicates from sampling site just below the surface of the river at 30 minutes intervals, using a pre-treated Winchester amber glass bottle with Teflon - lined screw cap. The treated water samples were also collected in triplicates by opening the tap at full flow for a few minutes before reducing the flow to fill the empty lipid-free Winchester bottle. 


\section{Sample Extraction and Analysis.}

About $10 \mathrm{~mL}$ of extracting solvent (HPLC grade) was added to the water sample immediately after collection, acidified $(\mathrm{pH} \leq 2)$ with concentrated $\mathrm{HCl}$ (Analytical grade) and stored at $4{ }^{\circ} \mathrm{C}$ in the cold room prior to extraction, method development and routine analysis. The clean up technique involves washing each of the solvent extracts with $10 \mathrm{~mL}$ of $0.1 \mathrm{M} \mathrm{Na}_{2} \mathrm{CO}_{3}$ solution ( 3 portions) and shaking for 10 min each time using a mechanical shaker set at $250 \mathrm{rpm}$. The $\mathrm{Na}_{2} \mathrm{CO}_{3}$ extracts were combined, and acidified to $\mathrm{pH} \leq 2$ with $2 \mathrm{M} \mathrm{HCl}$ and the FFAs further extracted with $10 \mathrm{~mL}$ x 3 portions of diethyl ether each time. The combined diethyl ether extracts were dried under anhydrous $\mathrm{Na}_{2} \mathrm{SO}_{4}$, filtered and evaporated to dryness with gentle stream of nitrogen gas. The dry FFA was then methylated, in a screw-capped test-tube heated to $80^{\circ} \mathrm{C}$ in a temperature regulated water bath, with $2 \mathrm{~mL} 14 \% \mathrm{BF}_{3}-$ Methanol for $5 \mathrm{~min}$. The methylation product was washed with $2 \mathrm{~mL}$ triply distilled water and $2 \mathrm{~mL}$ Hexane, vortexed for 1 minute and centrifuged at $500 \mathrm{rpm}$. The organic phase was collected, dried on anhydrous $\mathrm{Na}_{2} \mathrm{SO}_{4}$ and evaporated to dryness in a gentle stream of Nitrogen. Triplicate extractions and methylation were performed for the FFAs in each sample to illustrate the repeatability of the extraction technique while the analytes were run in the gas chromatography in duplicates.

The residue was reconstituted in a mixture of $0.8 \mathrm{~mL}$ Hexane and $0.2 \mathrm{~mL}$-butyl benzoate (internal standard) and $0.1 \mu \mathrm{L}$ of the dissolved residue of the methylated fatty acids was injected into a gas chromatograph with flame ionization detector (FID), (Varian Chrompack VA 3800) equipped with split injector. The capillary column used was $\mathrm{ZB}-5,30 \mathrm{~m} \times 0.25 \mathrm{~mm}$, i.d. $0.25 \mu \mathrm{L}$ film thickness. The stationary phase was 5\%-phenyl-95\%dimethylpolysiloxane. The GC / FID injector temperature condition was set at $260{ }^{\circ} \mathrm{C}$; Split ratio 1:50; FID at 300 ${ }^{0} \mathrm{C}$; Column $30 \mathrm{~m}$ x $0.25 \mathrm{~mm}$ i.d. x $0.25 \mathrm{uL}$ film thickness; T. Progr. $100{ }^{\circ} \mathrm{C}$ at $280{ }^{\circ} \mathrm{C}$ for $7 \mathrm{~min}$; flow rate $0.8 \mathrm{ml} / \mathrm{min}$.

\section{Results and Discussion:-}

Tables 1 and 2 contain the mean levels of FFAs in all the ten river water samples for the dry and wet seasons respectively. In the entire river water samples during the dry season (Table 1), the C12:0 ranged from 1.84 $\pm 0.56 \mu \mathrm{g} / \mathrm{L}$ to $34.86 \pm 7.45 \mu \mathrm{g} / \mathrm{L}$ with overall average of $11.74 \pm 10.76 \mu \mathrm{g} / \mathrm{L}$. The myristoleic acid $(\mathrm{C} 14: 1)$ content ranged from $0.47 \pm 0.11 \mu \mathrm{g} / \mathrm{L}$ to $4.07 \pm 0.74 \mathrm{ug} / \mathrm{L}$ with the overall average of $3.65 \pm 4.8 \mu \mathrm{g} / \mathrm{L}$. The levels of myristic acid (C14:0), however, ranged from $2.45 \pm 0.82 \mu \mathrm{g} / \mathrm{L}$ (Opa river) to $17.56 \pm 1.59 \mu \mathrm{g} / \mathrm{L}$ (Iju river) with average of $14.17 \pm 19.77 \mu \mathrm{g} / \mathrm{L}$. The palmitic acid (C16: 0) levels ranged from 7.25 $\pm 3.3 .94 \mu \mathrm{g} / \mathrm{L}$ to $138.62 \pm 25.22 \mu \mathrm{g} / \mathrm{L}$ with an average of $64.71 \pm 93.3$ $\mu \mathrm{g} / \mathrm{L}$. Stearic acid (C18:0) level ranged from $4.54 \pm 1.09 \mu \mathrm{g} / \mathrm{L}$ to $75.04 \pm 11.26 \mu \mathrm{g} / \mathrm{L}$ with an average of $22.86 \pm 24.9 \mu \mathrm{g} / \mathrm{L}$. The unsaturated carbon-18 FFA level ranged from $5.98 \pm 2.1 \mu \mathrm{g} / \mathrm{L}$ to $33.36 \pm 7.52 \mu \mathrm{g} / \mathrm{L}$ and the average level is $29.25 \pm 37.48 \mu \mathrm{g} / \mathrm{L}$.

In the wet season (Table 2), the level of lauric acid ranged from $1.89 \pm 0.36 \mu \mathrm{g} / \mathrm{L}$ to $22.31 \pm 5.30 \mu \mathrm{g} / \mathrm{L}$ with an overall mean of $12.27 \pm 14.40 \mu \mathrm{g} / \mathrm{L}$. The mean levels of myristoleic acid (C14:1) across the sites ranged between $1.0 \pm 0.20 \mu \mathrm{g} / \mathrm{L}$ to $9.73 \pm 2.46 \mu \mathrm{g} / \mathrm{L}$ with an average level of $3.99 \pm 3.68 \mu \mathrm{g} / \mathrm{L}$. The highest mean level of $\mathrm{C} 14: 1$ was observed in river Owena while the lowest was found in Ogbese. The mean concentration level of myristic acid in all the river water samples ranged from $2.47 \pm 0.41 \mu \mathrm{g} / \mathrm{L}$ to $36.23 \pm 2.12 \mu \mathrm{g} / \mathrm{L}$; highest and lowest levels were found in rivers Ose and Osun respectively. The levels of $\mathrm{C} 16: 0$ in the river waters ranged between $5.03 \pm 1.00 \mu \mathrm{g} / \mathrm{L}$ and $142.57 \pm 23.56 \mu \mathrm{g} / \mathrm{L}$. Considering the levels of the FFAs from each of the vertical column irrespective of the site studied, Table 2 also revealed the predominance of palmitic acid having the overall mean of $58.57 \pm 70.25 \mu \mathrm{g} / \mathrm{L}$ compared to all other FFA species in the river water samples of South-Western Nigeria. The highest level of C16:0 $(142.57 \pm 23.56 \mu \mathrm{g} / \mathrm{L})$ was found in Ose river water followed by Opa river $(59.61 \pm 5.70 \mu \mathrm{g} / \mathrm{L})$ and river Iju $(59.10 \pm 3.22 \mu \mathrm{g} / \mathrm{L})$. River Osun was observed to have the lowest level of palmitic acid $(5.037 \pm 1.00 \mu \mathrm{g} / \mathrm{L})$. The results showed that $\mathrm{C} 18 \mathrm{:u}$ rated next to palmitic acids in terms of predominance.

Apart from palmitic acid, the unsaturated Carbon-18 FFA (C18:u) and stearic acid (C18:0) are relatively high during the wet season. Across sites, the levels of $\mathrm{C} 18: 0$ and $\mathrm{C} 18: \mathrm{u}$ in all the river water samples during the wet season, ranged from $7.16 \pm 10.57 \mu \mathrm{g} / \mathrm{L}$ to $49.33 \pm 9.75 \mu \mathrm{g} / \mathrm{L}$ and $8.90 \pm 1.67 \mu \mathrm{g} / \mathrm{L}$ to $35.42 \pm 14.92$ respectively. The $\mathrm{C} 14: 1$ levels in all the water samples collected in both seasons are relatively low from site to site yielding an overall mean of $3.65 \pm 4.88$ and $3.99 \pm 3.68 \mu \mathrm{g} / \mathrm{L}$ for dry and wet seasons respectively (Tables 1 and 2) Hence, the least detected FFAs from the study area was C14:1.The data did not show any significant differences $(\alpha=0.05, \mathrm{p}=0.148-9.239)$ between levels of FFAs obtained between the two seasons. 
Though the FFA species vary from river to rivers the paired sample t-Test revealed that there are no significant differences in the mean levels of all the FFAs at 95\% conf. level among rivers Ala, Iju and Iyalaro. This suggests that all the FFAs in this set of rivers are statistically related as a group and hence there is the likelihood of common source(s) of fatty acid pollution for these rivers. Significant differences were, however, observed among the mean levels of the acids in the rest of the rivers, indicating that they are not statistically related and could have received fatty acid pollution from different sources.

Figure 2 also shows that the major FFA in the river waters sampled in both dry and wet seasons is palmitic acid contributing $45.04 \%$ and $42.65 \%$ respectively to the total FFAs in waters of the study area. This shows that river water samples from South-Western Nigeria are enriched in palmitic acids and unsaturated C-18 FFA.

High concentrations of FFAs were observed at Ogbese and Osun respectively while highest level was found in river Ose. The reason for the high levels of palmitic acid in the rivers may be attributed to common sources, which may likely include pollution via wastes from agricultural products, dead and decomposed aquatic animals, microbial activities etc. The highest level observed in river Ose may be due to fatty acid pollution from other unknown sources. Generally, in this study, palmitic acid (C16:0) predominates in all the river waters and is therefore significantly higher in the river samples than the rest of the FFA species studied.

Table 3 represents mean levels of FFAs in tap (municipal) waters processed from river Owena, Ose, Oni and Opa for dry and wet seasons. The table shows that the overall average of FFAs of the tap waters sampled in wet season ranged from $11.16 \pm 3.42 \mu \mathrm{g} / \mathrm{L}$ to $31.50 \pm 4.97 \mu \mathrm{g} / \mathrm{L}$. Tap water from River Owena had the highest overall average $(31.50 \pm 4.97 \mu \mathrm{g} / \mathrm{L})$ for FFAs followed by river Ose $(22.10 \pm 3.30 \mu \mathrm{g} / \mathrm{L})$ while tap water from river Oni gave the least overall level $11.16 \pm 3.42 \mu \mathrm{g} / \mathrm{L}$. In the dry season, the overall average levels of the six FFAs in the four tap water samples are: Oni $(19.93 \pm 8.76 \mu \mathrm{g} / \mathrm{L})$, Ose $(19.03 \pm 2.75 \mu \mathrm{g} / \mathrm{L})$, Owena $(10.68 \pm 1.64 \mu \mathrm{g} / \mathrm{L})$ and Opa $(6.14 \pm 3.30 \mu \mathrm{g} / \mathrm{L})$. In general, the data revealed that the FFAs in the tap waters are slightly higher in samples collected during wet season. An overview of the occurrence and environmental significance of the FFA species gives some insight into the circulation of FFAs through the various surface waters (raw water) via treatment processes in the drinking water. Thus, the percentages FFAs that migrated from the raw surface water into the municipal water which are graphically represented in figures 3a-e indicate the presence of FFAs in the municipal water supply in the study area. In Figure $3 \mathrm{e}$, Waterworks' in Opa and Ose stations appear to be more efficient in removing the trace organics (FFAs) from their raw water than the rest of the water work plants.

Table 1:- Mean* levels of FFAs $(\mu \mathrm{g} / \mathrm{L})$ in some river water samples of South-Western Nigeria in the dry season.

\begin{tabular}{|l|c|c|c|c|c|c|c|}
\hline & & & \multicolumn{2}{|c|}{ FFA Levels } & & & Overall \\
\hline River & $\mathrm{C} 12: 0$ & $\mathrm{C} 14: 1$ & $\mathrm{C} 14: 0$ & $\mathrm{C} 16: 0$ & $\mathrm{C} 18: \mathrm{u}$ & $\mathrm{C} 18: 0$ & Mean \\
\hline Ala & $7.58 \pm 1.20$ & $4.07 \pm 0.74$ & $9.04 \pm 1.01$ & $39.12 \pm 2.63$ & $19.21 \pm 2.194$ & $24.49 \pm 3.97$ & $17.25 \pm 1.96$ \\
\hline Iju & $17.89 \pm 2.15$ & $1.53 \pm 0.17$ & $17.56 \pm 1.59$ & $36.47 \pm 4.56$ & $18.68 \pm 2.64$ & $14.96 \pm 3.34$ & $17.85 \pm 2.41$ \\
\hline Iyalaro & $6.88 \pm 1.21$ & $3.65 \pm 0.90$ & $10.94 \pm 3.51$ & $69.42 \pm 6.64$ & $30.34 \pm 4.98$ & $32.13 \pm 3.72$ & $24.72 \pm 3.5$ \\
\hline Ogbese & $1.84 \pm 0.56$ & $0.47 \pm 0.11$ & $2.81 \pm 0.60$ & $10.80 \pm 1.35$ & $8.10 \pm 1.01$ & $5.75 \pm 1.12$ & $4.96 \pm 0.8$ \\
\hline Oluwa & $8.16 \pm 0.97$ & $1.7007 \pm 0.31$ & $7.68 \pm 3.87$ & $42.46 \pm 4.63$ & $24.63 \pm 3.73$ & $12.87 \pm 1.71$ & $16.26 \pm 2.54$ \\
\hline Oni & $25.34 \pm 2.93$ & $1.57 \pm 2.88$ & $7.07 \pm 14.00$ & $55.36 \pm 34.07$ & $12.81 \pm 31.81$ & $9.87 \pm 6.76$ & $19.17 \pm 15.41$ \\
\hline Opa & $12.42 \pm 0.23$ & $2.38 \pm 0.17$ & $2.45 \pm 0.82$ & $12.14 \pm 2.54$ & $7.64 \pm 1.59$ & $4.54 \pm 1.09$ & $5.26 \pm 1.07$ \\
\hline Ose & $34.68 \pm 7.45$ & $1.50 \pm 0.33$ & $17.19 \pm 3.06$ & $138.62 \pm 25.22$ & $33.36 \pm 7.52$ & $75.04 \pm 11.26$ & $48.40 \pm 9.14$ \\
\hline Osun & $2.84 \pm 0.75$ & $0.90 \pm 0.00$ & $2.60 \pm 0.43$ & $7.25 \pm 3.94$ & $7.51 \pm 1.30$ & $18.60 \pm 3.82$ & $6.62 \pm 1.71$ \\
\hline Owena & $9.78 \pm 2.48$ & $2.23 \pm 0.71$ & $3.32 \pm 0.84$ & $58.86 \pm 1.01$ & $5.98 \pm 2.10$ & $4.78 \pm 0.55$ & $5.82 \pm 1.28$ \\
\hline
\end{tabular}

Note : C12:0 = Lauric acid; C14:1 = Myristoleic acid; C14:0 = Myristic acid; C16:0 = palmitic acid; 18:0 = stearic acid, C18:u = unsaturated FFAs, sd = standard deviation.

Table 2:- Mean $( \pm \mathrm{sd})$ levels of FFAs $(\mu \mathrm{g} / \mathrm{L})$ in some river waters of South-western Nigeria in the wet season.

\begin{tabular}{|l|l|l|l|l|l|l|l|}
\hline & \multicolumn{3}{|c|}{} & FFA Levels & & \multicolumn{2}{l|}{ Overall } \\
\hline River & $\mathbf{c 1 2 : 0}$ & C14:1 & C14:0 & C16:0 & C18:u & C18:0 & Mean \\
\hline Ala & $9.29 \pm 1.27$ & $3.65 \pm 1.00$ & $14.19 \pm 2.09$ & $38.78 \pm 5.72$ & $27.83 \pm 5.77$ & $16.17 \pm 4.57$ & $18.32 \pm 3.40$ \\
\hline Iju & $5.52 \pm 1.19$ & $3.62 \pm 0.29$ & $10.66 \pm 1.18$ & $59.10 \pm 3.22$ & $17.14 \pm 1.70$ & $28.63 \pm 5.22$ & $20.78 \pm 2.14$ \\
\hline Iyalaro & $8.77 \pm 1.02$ & $3.82 \pm 0.50$ & $8.73 \pm 2.52$ & $37.87 \pm 2.21$ & $21.97 \pm 3.19$ & $22.25 \pm 2.34$ & $17.24 \pm 1.96$ \\
\hline Ogbese & $1.89 \pm 0.36$ & $1.00 \pm 0.20$ & $5.57 \pm 0.71$ & $15.74 \pm 2.81$ & $16 . .81 \pm 2.90$ & $11.8 \pm 2.89$ & $7.97 \pm 1.64$ \\
\hline
\end{tabular}




\begin{tabular}{|l|l|l|l|l|l|l|l|}
\hline Oluwa & $7.54 \pm 0.99$ & $1.45 \pm 0.07$ & $27.43 \pm 3.15$ & $15.72 \pm 3.95$ & $19.46 \pm 1.63$ & $10.04 \pm 1.75$ & $13.61 \pm 1.92$ \\
\hline Oni & $5.36 \pm 4.77$ & $1.22 \pm 2.64$ & $6.63 \pm 7.13$ & $24.41 \pm 36.60$ & $10.76 \pm 15.02$ & $7.16 \pm 10.56$ & $9.25 \pm 12.77$ \\
\hline Opa & $14.11 \pm 2.35$ & $4.23 \pm 0.65$ & $9.62 \pm 1.75$ & $59.61 \pm 5.70$ & $23.91 \pm 3.41$ & $21.47 \pm 2.29$ & $22.12 \pm 2.69$ \\
\hline Ose & $11.89 \pm 2.68$ & $2.23 \pm 0.46$ & $36.23 \pm 2.12$ & $142.57 \pm 23.56$ & $35.42 \pm 14.95$ & $49.33 \pm 3.76$ & $46.23 \pm 8.92$ \\
\hline Osun & $2.88 \pm 0.32$ & $1.67 \pm 0.23$ & $2.47 \pm 0.41$ & $5.03 \pm 1.00$ & $8.90 \pm 1.67$ & $15.16 \pm 4.82$ & $6.02 \pm 1.40$ \\
\hline Owena & $22.31 \pm 5.30$ & $9.73 \pm 2.46$ & $16.07 \pm 7.34$ & $53.22 \pm 2.53$ & $20.15 \pm 2.49$ & $13.30 \pm 2.41$ & $22.46 \pm 3.76$ \\
\hline
\end{tabular}

Note : C12:0 = Lauric acid; C14:1 = Myristoleic acid; C14:0 = Myristic acid; C16:0 = palmitic acid; 18:0 = stearic acid, C18:u = unsaturated FFAs, sd = standard deviation.

Table 3:- Mean levels ( \pm sd) of FFAs in some tap waters of South-Western Nigeria.

\begin{tabular}{|c|c|c|c|c|c|c|c|c|}
\hline Season & River Source & & \multicolumn{3}{|c|}{ FFA Levels (ug/L) } & & Overall \\
\hline Wet & & C12:0 & C14:1 & C14:0 & C16:0 & C18:u & C18:0 & mean \\
Season & Opa & 18.25 & 0.63 & 13.70 & 21.23 & 17.39 & 10.82 & 13.67 \\
\hline & & \pm 1.90 & \pm 0.04 & \pm 3.27 & \pm 4.78 & \pm 3.39 & \pm 3.77 & \pm 3.42 \\
\hline & Owena & 17.12 & 1.21 & 21.13 & 85.12 & 50.29 & 14.15 & 31.5 \\
\hline & & \pm 10.72 & \pm 0.51 & \pm 4.77 & \pm 5.79 & \pm 4.07 & \pm 3.98 & \pm 4.97 \\
\hline & Oni & 15.64 & 4.44 & 9.13 & 15.97 & 13.25 & 8.53 & 11.16 \\
\hline & & \pm 3.99 & \pm 2.87 & \pm 7.73 & \pm 14.1 & \pm 9.74 & \pm 2.09 & \pm 6.75 \\
\hline & Ose & 22.66 & 0.98 & 21.84 & 30.83 & 31.94 & 24.32 & 22.1 \\
\hline & & \pm 4.40 & \pm 3.48 & \pm 1.98 & \pm 3.1 & \pm 3.85 & \pm 2.99 & \pm 3.3 \\
\hline Dry & & & & & & & & \\
\hline Season & Opa & 8.06 & 2.85 & 3.21 & 10.31 & 7.67 & 4.71 & 6.14 \\
\hline & & \pm 6.64 & \pm 2.02 & \pm 7.11 & \pm 17.11 & \pm 19.05 & \pm 7.74 & \pm 3.30 \\
\hline & Owena & 7.71 & 0.86 & 10.33 & 36.22 & 4.61 & 4.3561 & 10.68 \\
\hline & & \pm 3.67 & \pm 0.36 & \pm 0.84 & \pm 2.69 & \pm 1.72 & \pm 0.55 & \pm 1.64 \\
\hline & Oni & 18.00 & 6.26 & 18.68 & 45.95 & 9.98 & 10.78 & 19.93 \\
\hline & & \pm 3.00 & \pm 4.17 & \pm 13.66 & \pm 9.87 & \pm 10.52 & \pm 11.31 & \pm 8.76 \\
\hline & Ose & 14.78 & 0.89 & 19.86 & 44.46 & 23.56 & 10.63 & 19.03 \\
\hline & & \pm 3.33 & \pm 0.18 & \pm 6.02 & \pm 2.44 & \pm 3.37 & \pm 1.17 & \pm 2.75 \\
\hline
\end{tabular}

Note : C12:0 = Lauric acid; C14:1 = Myristoleic acid; C14:0 = Myristic acid; C16:0 = palmitic acid; 18:0 = stearic acid, C18:u = unsaturated FFAs, sd = standard deviation. 


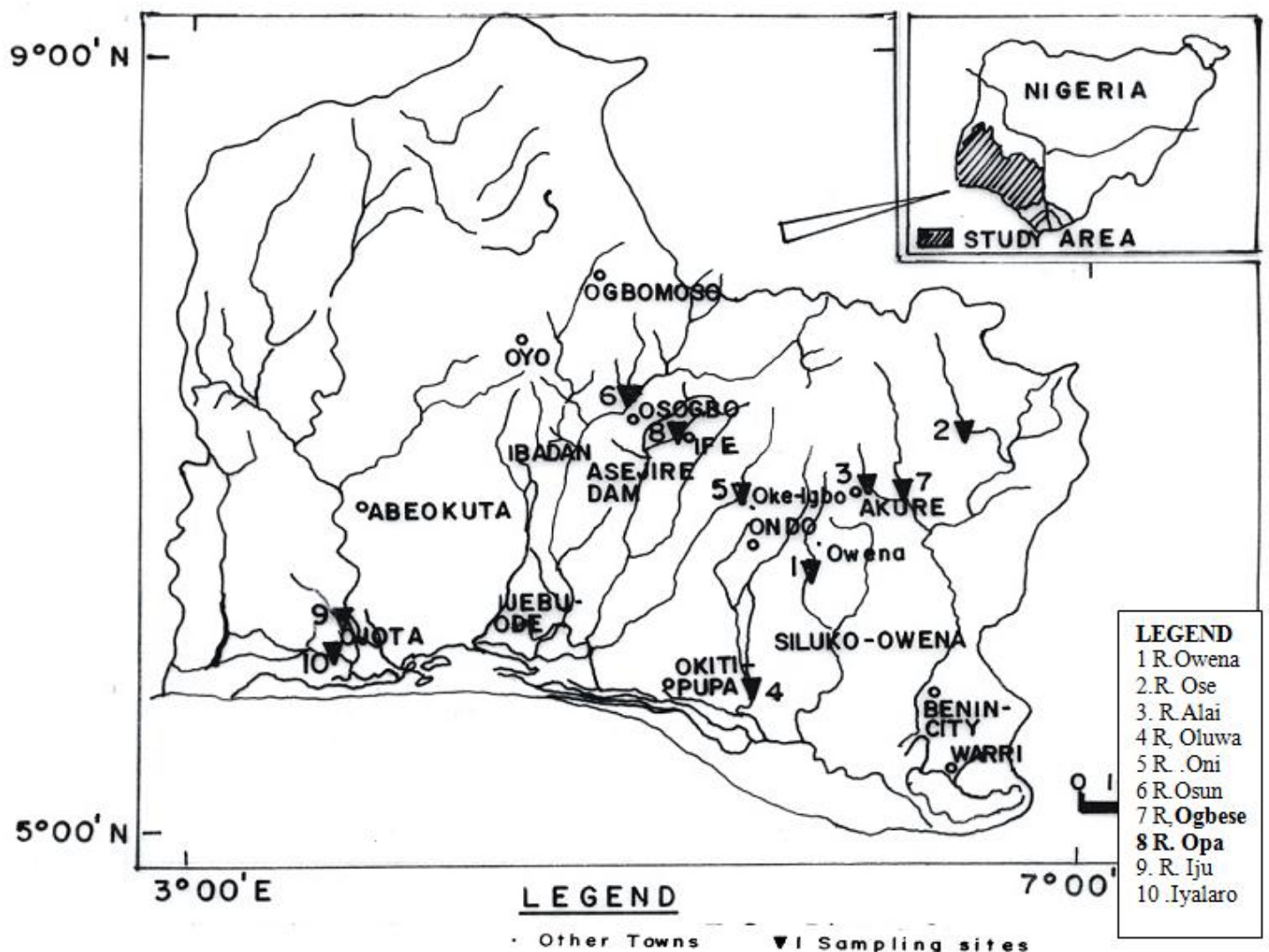

Figure 1:- Map of South-Western Nigeria showing major rivers and sampling sites.

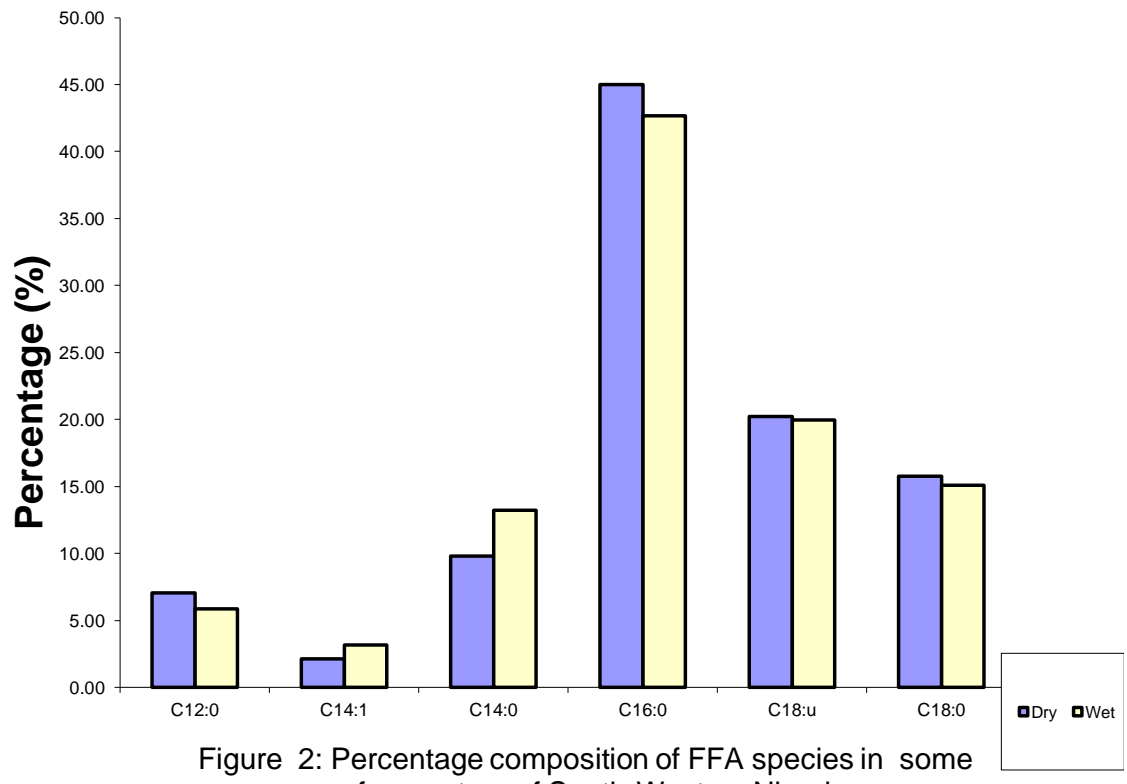
surface waters of South-Western Nigeria. 


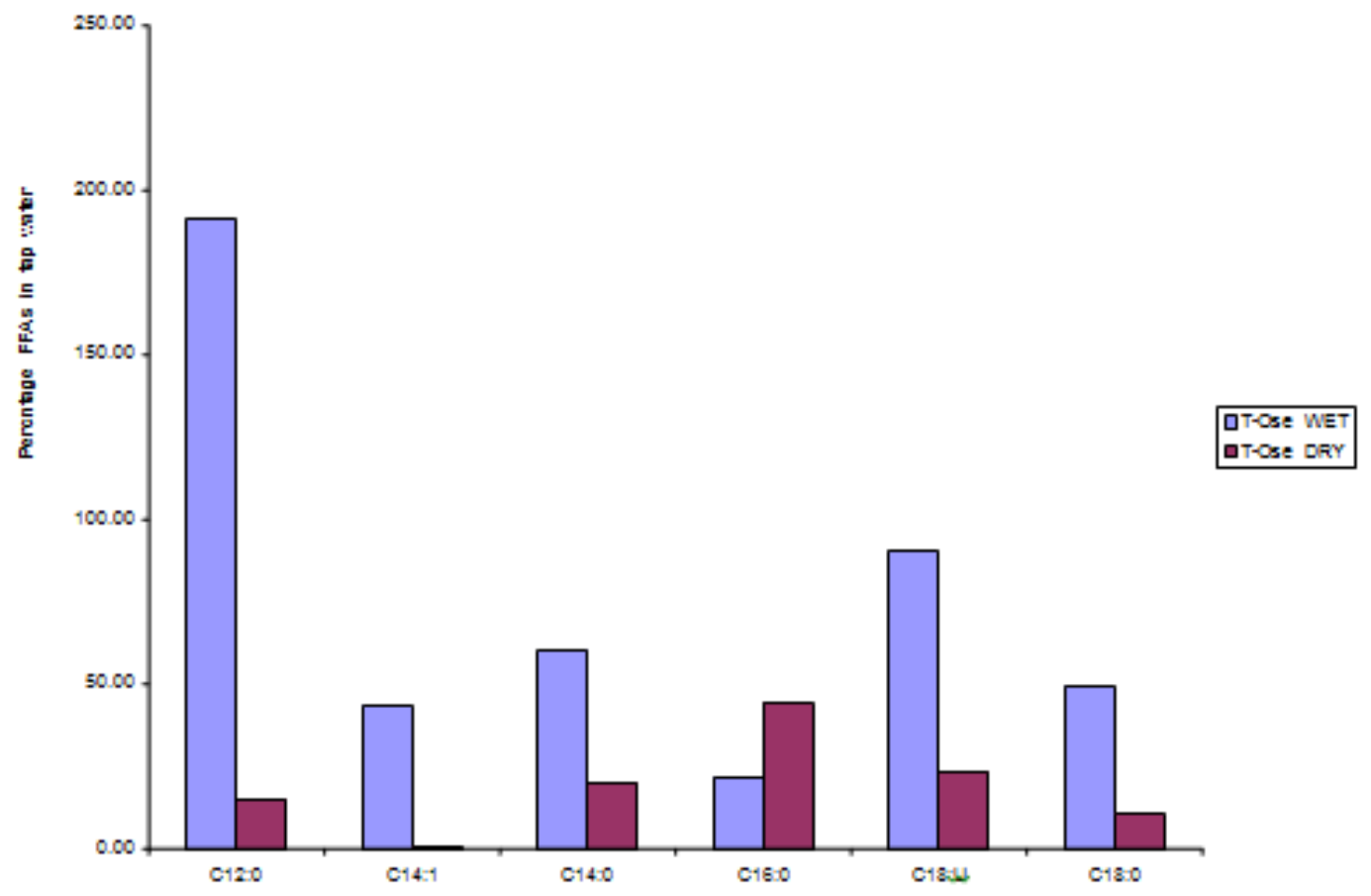

Figure 3a:- Percentages of FFAs that migrate from river Ose into the tap water.

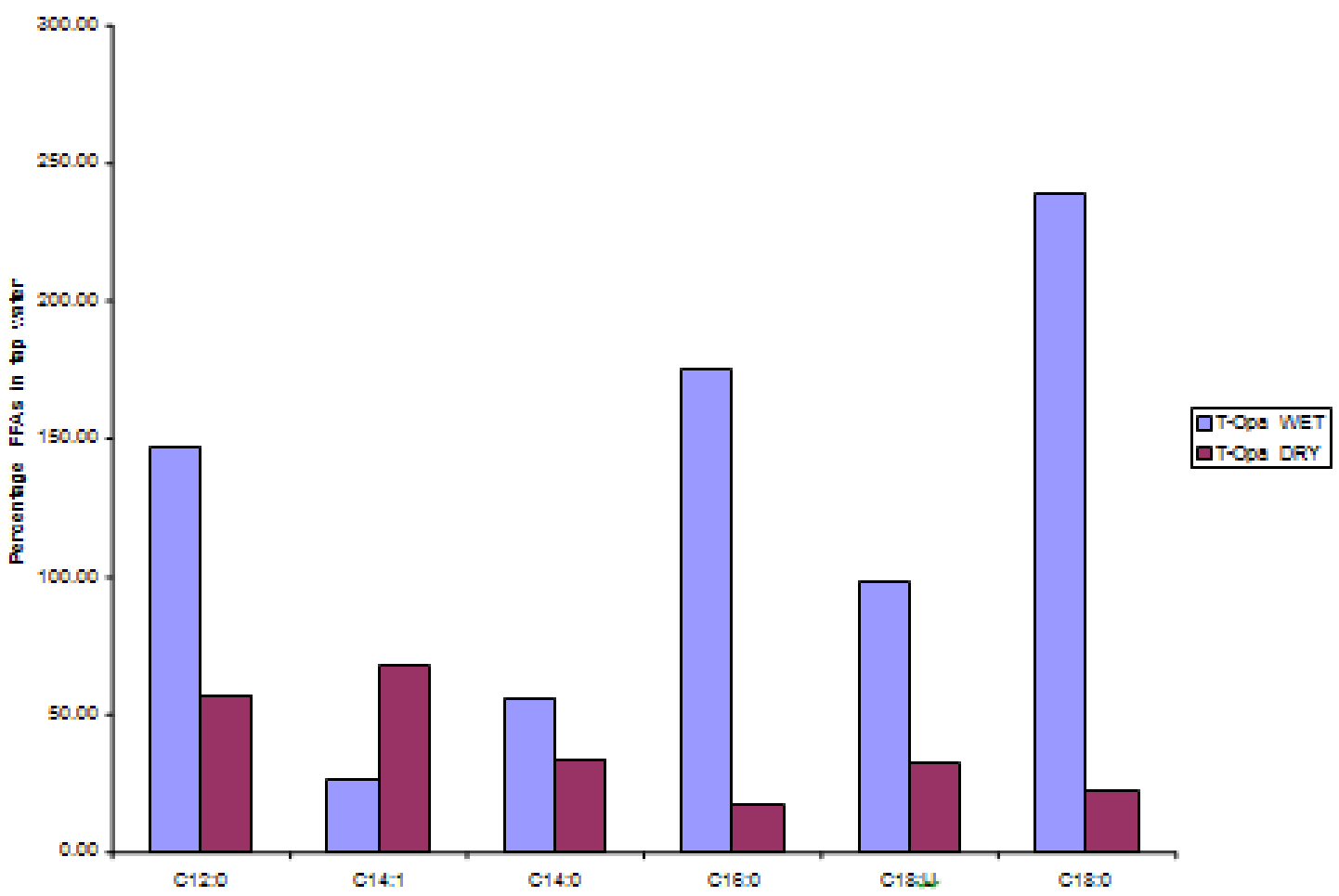

Figure 3b:- Percentages of FFAs that migrate from river Opa into the tap water. 


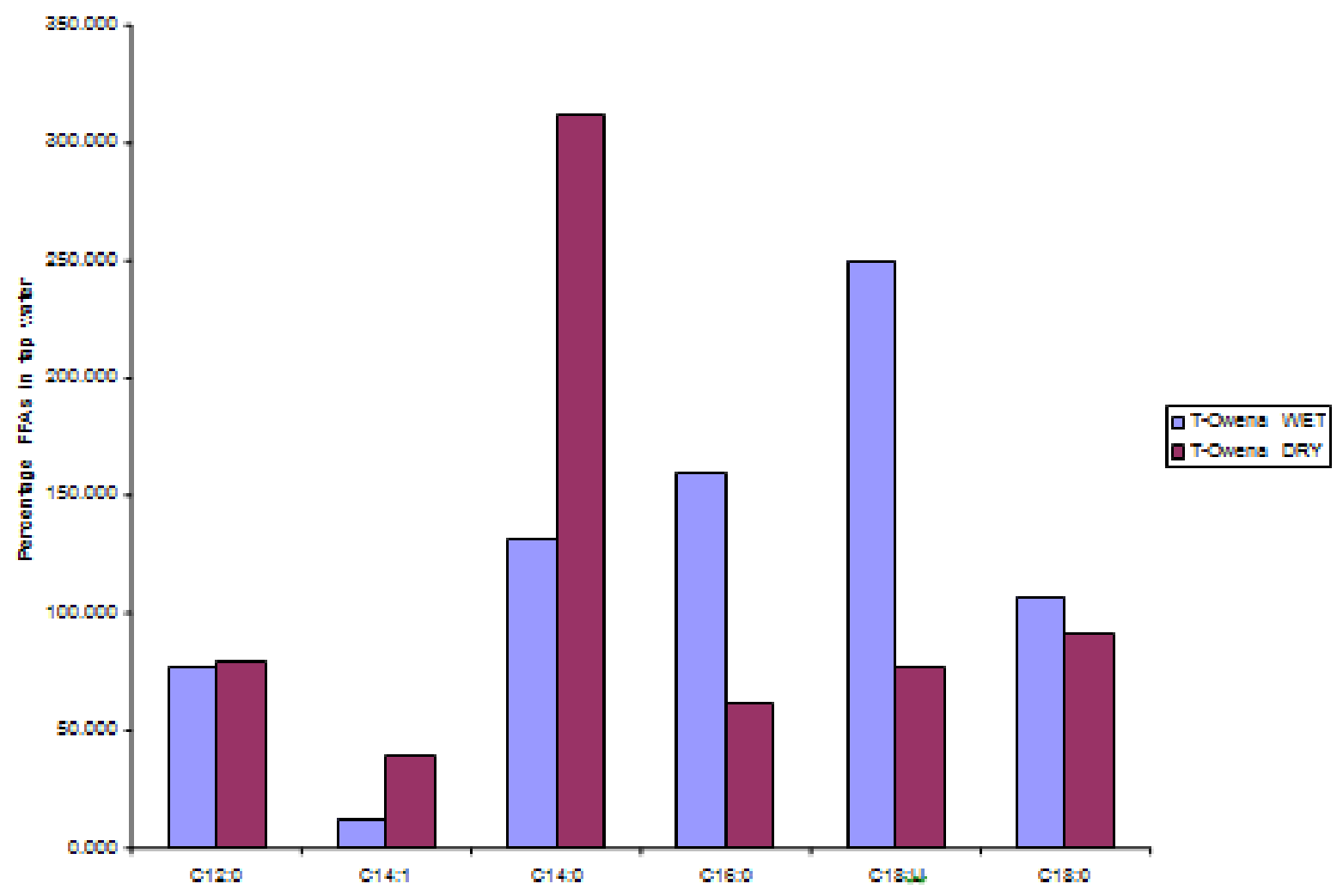

Figure 3c:- Percentages of FAs that migrate from river Owena into the tap water.

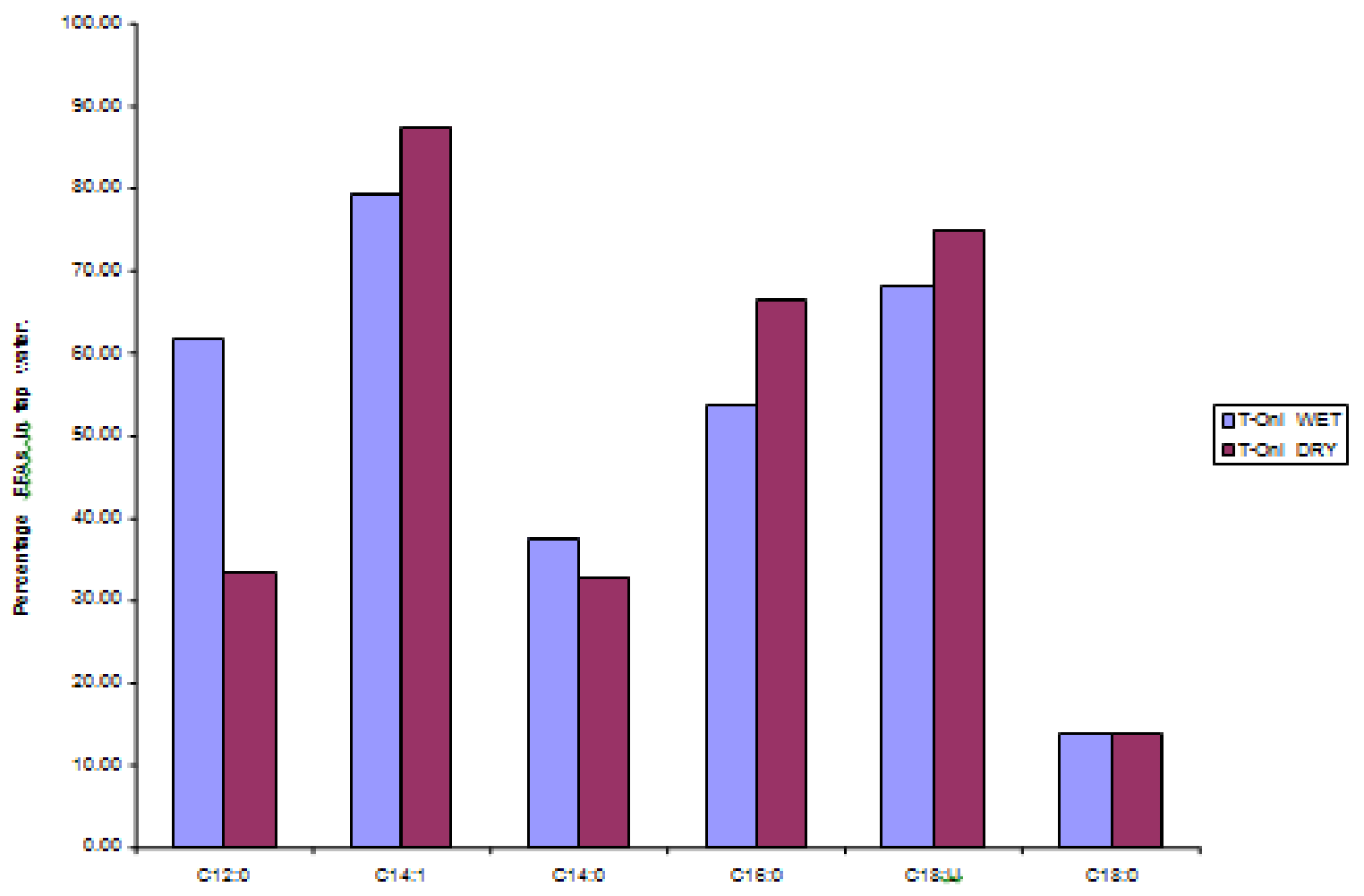

Figure 3d:- Percentages of FFAs that migrate from river Owena into the tap water. 


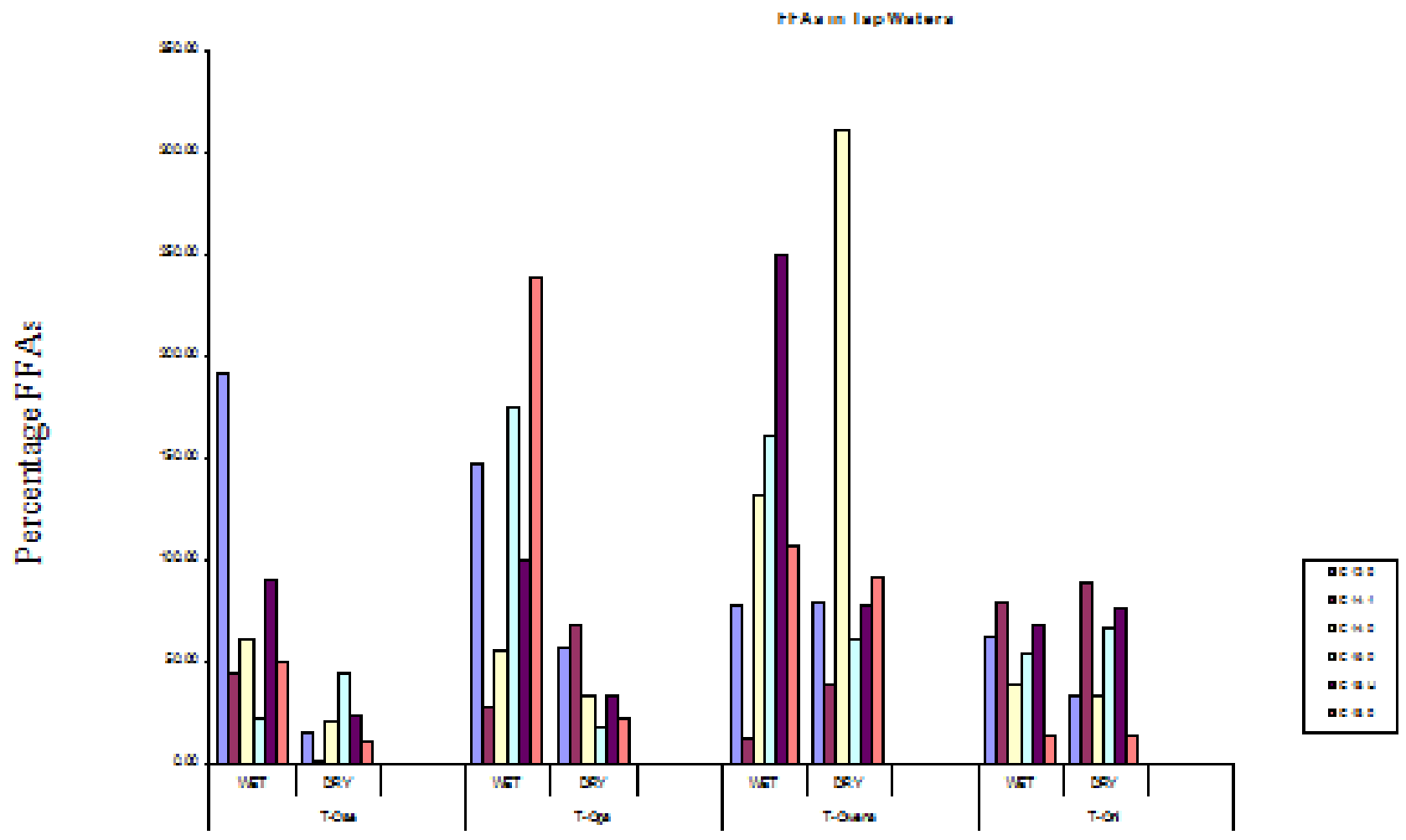

Figure 3e:- Percentages of FFAs that migrate from surface waters into tap waters of S.W. Nigeria.

\section{Conclusion:-}

This study reveals the qualitative and quantitative distribution of free fatty acids in treated drinking water and surface waters of South-Western Nigeria. It was established that free fatty acids are present in surface and pipeborne waters of Nigeria in varying degrees, the predominant FFA species being palmitic acid (C16:0) followed by unsaturated C-18 fatty acid (C18:u) and stearic acid (C18:0). Lauric acid (C12:0) and myristic acid (C14:0) are present in medium concentration while myristoleic acid (C14:1) is present in trace quantities.

It is also concluded that most of the FFAs in the surface waters migrated into the treated drinking water and that the water treatment plants in the study area have minimal effect on the removal of FFAs from the raw waters. The FFAs may be introduced into the treated water via seepage from damaged underground water pipes, as their levels are higher in the tap waters during the wet season than in the dry season and sometimes more in the tap waters than in raw surface waters. However, more intensive research is also required on the extraction efficiencies of the water work plants for removal of trace organics, especially FFAs, from drinking water. 


\section{References:-}

1. Ayvas, G. B. Alos, Y. F., Karakoc, A, Yetkin, I., Cakin, N., and Arslan, M.(2002): Acute and chronic effect of different concentrations of free insulin secreting function of free fatty acid insulin secreting function of islet. Diabetes. Matab, $28(6 \mathrm{Pt}+2)$ : 3S7 - 12: Discussion 3S108 - 112 .

2. Boden, G (2002): Interaction between free fatty acids and glucose metabolism. Curr. Opi. Clin. Nutr. Metab. Care Se 545 - 549. Review PMID: 12172479 (Pub MED - Indexed for MEDLINE ).

3. Byrnes, G. (2002): Diet and Heart Diseases - It's not what you think. Available at www. Bethesda Press.com

4. Christie, W.W (1993) Methyl esters of fatty acids preparation. In: W.W. Christie, Editor.

5. Advances in lipid methodology - II. The Oil Press, Dundee, pp 69 - 111.

6. Donald W. Meals, R. Peter Richards and Steven A. Dressing.( 2013). Pollutant load estimation for water quality monitoring projects. Tech Notes 8, April 2013, Developed for U.S.

7. Environmental Protection Agency by Tetra Tech, Inc., Fairfax, VA, 21 p. Available online at https://www.epa.gov/polluted-runoff- nonpoint- source-pollution/nonpoint-source-monit.

8. Enig, M. G. (1995): Trans Fatty Acids in Food Supply: A Comprehensive Report Covering 60 Years Research. $2^{\text {nd }}$ Ed. Enig Associates I N C, Maryland.

9. Fatoki, O .S. and Vernon, F. (1989): Determination of Free Fatty Acid Content of Polluted and Unpolluted Waters. Water Res., 23 (1): 123-125

10. Holmes M.D. (1999): Association of dietary intake of fats and fatty acids with risk of breast cancer. J. Amer. Med. Assoc. 281:914 -920.

11. Ishiwatari, R. and Hanya, T. (1974): Gas chromatographic spectrometric identification of organic compounds in river water, In: Tissort B. \& Biener, F, Editors. Advances in organic Geochemistry, 1973. $3^{\text {rd }}$ Edition Techning, Paris, pp1051 -1065.

12. Lobna Ouldamer, Caroline Goupille, Anne Vildé, Flavie Arbion, Gilles Body, Stephan Hevalier, Jean Philippe Cottier, Philippe Bougnoux (2016). N-3 Polyunsaturated Fatty Acids of Marine Origin and Multilocality in Human Breast Cancer. PLOS. Retrieved from https://doi.org/10.1371/journal.pone.0147148, accessed on $18 / 05 / 2017$.

13. Mann, G. (1994): Metabolic consequence of Dietary Trans - fatty acids. Lancet, 343: 1268 - 1271.

14. Matsumoto, G. (1981): Comparative study on organic constituents in polluted and unpolluted inland aquatic environment - II: Features of Fatty acids for polluted waters. Water. Res. 15: 779-787

15. Sheldon L.S and Hites R.A [1978]: Organic compounds in the Delaware River. Environ Sci. \& Tech, 12 : 1188 - 1194 Simona Cernea and Minodora Dobreanu (2013). Diabetes and beta cell function: from mechanisms to evaluation and clinical implications. Biochem Med (Zagreb). 23(3): 266-280

16. Dart, R. K. and Stretton, R. S. (1977): Medicinal aspect of Pollution Control. Elsevier Scientific Publ. Co. Amsterdam, 215p Holmes M.D. (1999): Association of dietary intake of fats and fatty acids with risk of breast cancer. J. Amer. Med. Assoc. 281: $914-920$.

17. Kelley, P.B., Reiser, R. and Hood, D.W. (1959): The origin of marine polyunsaturated fatty acid composition of some marine plankton. J. Am. Oil Chem. Soc. 35: 104 - 106.

18. Lizuka, K., Nakajima, H., Namba, M., Miyazaki, J. Hanafusa, T. and Matsuzawa, Y. (2002):

19. Metabolic consequence of long - term exposure of pancreatic fatty acids with special reference to glucose insensibility, BiochemBiophysActa. 1586: 23 - 31.

20. Morgan, M. (1977): Rural Water Supplies and Sanitation. McMillam Ed. Publ. Ltd. London. Pp $252-254$.

21. Ogura, N., Anise .Y., Ogura, K., Ishiwatari, T., Satoh Y., Matsushima .H., Katase, T., Ochiai, M., Tadokoro, K., Yakadi, T, Sughara, K., Matsumoto, G., Nakamoto, M., Funakoshi, M., and Hanya T. (1975): Chemical composition of organic Compounds present in water of Tamagawa River. Jap. J. Limnol. 36: 23-30.

22. Sawkins, F.J., Chase, C.G., Derby, D.G, and Rapp, G. (1978): A Text Book in Physical Geology. $2^{\text {nd }}$ Ed., Collier Mac-millian Inter. Ed.; Pp. 386 - 410. 